\title{
NARRATIVES OF A DESIGNER'S COLLECTION: FASHION SHOWS AND ARTISTIC APPLICATIONS
}

\author{
Sanem ODABAȘI \\ Eskişehir Technical University, Turkey \\ odabasisanem@gmail.com \\ https://orcid.org/0000-0001-8467-9038
}

\begin{abstract}
Fashion weeks are of significant importance since in addition to new designs to present, within those weeks a fashion shows' effect sometimes moves ahead of the designs. When collections are completed, fashion designers introduce them through the "fashion show," a field used to present their collection ideas in an impressive and striking manner. Through this form, the designer employs performative presentation to help put across the intellectual message, the allure of a fashionable creation, or to mediate diverse creations in a visual way as a collection. Fashion shows have a strong impact due to the atmosphere created which is surrounded by music, video art, performance and stage design. These 20-25 minute shows represent the whole collection through the background idea of the collection and designer's inner world, by using colors, textures, stories, forms and visuals. Thus, an artistic approach is key when designing a show in order to reveal the collection's idea in its most relevant form. The aim of this paper is to examine how fashion shows are curated by artistic applications and to reveal the ways of narrating stories which are not written but are conveyed to communities through performative presentations. In this respect, an interpretative approach was adopted and related artistic applications from contemporary examples held between 2013 and 2018 were analyzed as part of narrating a collection. The finding of this study is that the audience has gained a new role as becoming participants in the fashion shows themselves with the opportunities offered by technological developments which creates new meanings for the fashion shows. It is understood that the function of fashion shows is now changing from a means of promotional to audience communication.
\end{abstract}

Keywords: Fashion Shows, Fashion and Art, Fashion and Technology, Narratives of Fashion.

\section{TASARIMCININ KOLEKSIYON ANLATILARI: MODA GÖSTERILERİ VE SANATSAL UYGULAMALAR}

\section{ÖZ}

Moda haftaları, yeni tasarımların sunuluyor olmasının yanı sıra, etkisinin bazen tasarımların önüne de geçebildiği ciddi bir öneme sahiptir. Moda tasarımcıları koleksiyonlarını tamamladığında, koleksiyonun ana fikrini etkin ve çarpıcı bir biçimde sergilemek için tasarımlarını "moda gösterileri" aracılığıyla sunmaktadır. Bu yöntemle tasarımcı, düşünsel mesajını, koleksiyonun büyüsünü iletmek veya farklı yaratıları bir koleksiyon olarak görsel bir şekilde ifade etmek amacıyla performatif bir sunum kullanır. Bu yönüyle moda gösterileri, müzik, video sanatı, performans ve sahne tasarımı ile çevrelenmesinden ötürü güçlü bir etkiye sahiptir. Bu 20-25 dakika süren gösteriler, renk ve dokular, hikâyeler, biçimler ve görseller kullanılarak tasarımcının iç dünyasını ve koleksiyonun arka planındaki fikirleri temsil etmektedir. Bu nedenle, koleksiyonun fikrini en uygun biçimde ortaya koymak için bir gösteri tasarlarken sanatsal bir yaklaşımda bulunmak önemlidir. $\mathrm{Bu}$ makalenin amacı moda gösterilerinin ne tür sanatsal uygulamalar gerçekleştirdiğini incelemek ve gösterilere ait yazılı olmayan, fakat performatif sunumlarla anlatılan hikâyelerin topluluklara hangi sunum şekilleriyle aktarıldığını ortaya koymaktır. Bu doğrultuda, yorumsamacı bir yaklaşım benimsenmiş olunup, konuyla ilişkin güncel örnekler 2013-2018 yılları arasında düzenlenen moda gösterilerindeki sanatsal

Submit Date: 03.04.2019, Acceptance Date: 04.08.2019, DOI NO: 10.7456/10904100/006 546

Research Article - This article was checked by Turnitin

Copyright (C) The Turkish Online Journal of Design, Art and Communication 
uygulamalardan elde edilerek koleksiyon anlatımının bir parçası olarak incelenmiştir. Makalenin bulgusu, teknolojik gelişmelerin sunduğu olanaklarla yeni anlamlar kazanan moda gösterilerindeki izleyicinin performansı gözlemleyen kişi olmaktan sıyrılarak, moda gösterilerine bizzat katılan kişi olarak yeni bir rol edindiği üzerinedir. Moda gösterilerinin işlevinin artık tanıtım araçlarından farklılaşarak, izleyiciyle iletişim kurma yönünde değiştiği anlaşılmaktadır.

Anahtar kelimeler: Moda Gösterileri, Moda ve Sanat, Moda ve Teknoloji, Moda Anlatılarl.

\section{INTRODUCTION}

London, Paris, New York, and Milan are known to be the four main centers of fashion, and within their fashion weeks are intense events where designers offer their fall-winter, spring-summer and resort collections. The major shows in those cities are often covered on tv news broadcasts, newspapers and magazines. Fashion is clearly seen as important enough to warrant such a lavish degree of attention-or it is all the attention that makes fashion important (Svendsen, 2006: 10). Fashion weeks contain several exciting events that represent their character; creating new design-oriented values, revealing new collections by the designers, new details or the use of an innovative material by a designer in a new collection, and the presentation of inventions. The overall magnificence and impressive atmosphere of fashion shows brings further dynamism to fashion weeks. They are of significant importance since in addition to the new designs presented, within those weeks the fashion shows' effect sometimes moves ahead of the designs. Displaying a new collection from a designer in an artistic venue adds great excitement for the attending and viewing audience.

Fashion shows have a strong impact due to their atmosphere, surrounded by music, video art, performance and stage design. These 20-25 minute shows represent the whole collection with the background idea of the collection and designer's inner world through the use of colors, textures, stories, forms and visuals. Thus, an artistic approach is a necessity when designing a show in order to reveal the most notable character of a collection. In today's fashion scene, it can be observed that fashion creates verbal stories an narratives by using different forms of art, and so fashion shows do too. For this reason, there is also a narrative to each fashion show which can be identified as a common share among people and social groups. The aim of this paper is to examine how fashion shows are curated by artistic applications and to reveal the ways of narrating stories which are not written but are conveyed to communities through performative presentations. In this respect, an interpretative approach was adopted and the related examples were analyzed and presented. In this paper, examples from different fashion shows are stipulated in order to a better understanding of the social interaction and situations as a process of interpretation (Marshall and Scott, 1999). To portray more contemporary examples, shows held between 2013 and 2018 are represented as the object of this paper, and fashion shows and their artistic application discussed as part of narrating a collection and theme. The shows that are chosen for this paper has their own unique features since they are using visual designs, cinematography, sculpture, music and poetry in contributing distinct and authentic value for each show. The fashion shows of Chanel, Gucci, Louis Vuitton, DKNY, Opening Ceremony, Viktor and Rolf, Kenzo and Marc Jacobs are discussed in this article due to their progressive touch in these fashion shows with the collaborations they made that created outstanding visual designs and artistic applications and the participation of the audience in fashion shows which can be stated as becoming a new phenomenon for 21 st century. The interpretation of these shows that are mentioned has a key element for accumulating a deeper knowledge, for this reason, an analytical approach rather than a descriptive one was obtained for this paper within a textual expression.

\section{FASHION SHOWS}

The most artistic aspect of fashion is normally linked to its display (Svendsen, 2006: 98). The idea of dressing models, parading them down a catwalk, and premiering a new collection to the press was born out of the Chicago apparel marts of the early 1900's. By the mid-1930's, the shows were

Submit Date: 03.04.2019, Acceptance Date: 04.08.2019, DOI NO: 10.7456/10904100/006 
produced on a grand scale, and in the 1960's, sound and light were integrated into runway productions (Duggan, 2001: 245). In Europe, based on the works of Charles Frederick Worth, Paul Poiret, and Lucile (known as Lucy Christiana, Lady Duff-Gordon), the concept of the fashion designer was pioneered in the early 20th century, with designers such as Lucile and Worth starting to organize fashion shows that employed professional models in order to promote their fashion houses (Arnold, 2009: 14). These designers scarcely have imagined how fashion shows would develop towards the end of the century (Svendsen, 2006: 98-99). Fashion shows have progressed immeasurably since, and today they significantly utilize performance arts and digital technologies in order to create different effects.

The definition of a fashion show has been described as "a biannual presentation of a new clothing collection on moving bodies for an audience" (Skov et al., 2009: 2). Didier Grumbach, the former president of Chambre Syndicale de Haute Couture also stated that the fashion show is a tool that means to narrate a designer's ideas (Tungate, 2006: 161). Over one-hundred years since inception, today's fashion show is more abundant and the means more varied. From the "manikin doll" type to the professional catwalk performance seen in the commercial world, to the international costume design and modeling competitions as well as the artistic program which aims to satisfy an audience's appreciation of beauty, the fashion show has formed into a rich and colorful performance type (Xu and Zhang, 2011: 607). Today, when collections are completed, fashion designers introduce them through the "fashion show," a field used to present their collection ideas in an impressive and striking manner. Through this form, the designer employs performative presentation to help put across the intellectual message, the allure of a fashionable creation, or to mediate diverse creations in a visual way as a collection. This is a one-off opportunity for a designer to present the character of his or her clothing from the creator's viewpoint (Loschek, 2009: 80). Fashion show stage designs are of extreme importance in order to leave the correct impression with the audience, and to narrate the stories behind the designs. Generally, stages are formed in L, T, X, or H shapes in order that models can easily maneuver on a long catwalk so that their audience can view a particular garment for an average of 90 seconds. Even though things referred to and displayed through an outfit including cosmetics, accessories and hairstyle are ambiguous and vague when compared to normal dialogue and writing, clothing is generally perceived within a general concept of code.

Different dress combinations can create new meanings for those who view, model, and wear them (Davis, 1997: 24). Fashion has permeated through virtually all aspects of culture. Once we widen our gaze from the realm of clothes and consider fashion as a phenomenon, we can clearly see that fashion lies in the centre of the modern world (Svendsen, 2006: 10). In a world dependent upon visual representation, fashion has become an important tool for the communication and representation of one's persona (Barnard, 2013: 27; Kuruc, 2008: 196). Davis considered dresses as a tool of communication, but also stated that significant differences between the indicatives of the dress that are not clearly defined when compared to verbal sounds in dialogue-based communication (1997: 24-25). Thus, with the fashion shows, designers search not only for creative product inventions, but also for inventive presentations that do justice to the philosophy of their design and fashion, and to the intended message behind their clothing (Loschek, 2009: 80). When the world of fashion is defined as a sequence of creating codes and values, there is no doubt that fashion shows are a platform (area) organized to reveal these meanings and non-verbal expressions and, consequently, it is presented as a stage show.

\section{FASHION SHOWS AS NARRATIVES AND COMMUNICATIVE TOOLS: EXAMPLES FROM FASHION SHOWS}

In their study, Enwistle and Rocamora suggested that one of the major purposes of the fashion show is to see and been seen, and by one's being seen one's position in the field is reproduced (2006: 743). The notion of the field is based on the field theory of Bourdieu, as a "system" which has specific rules of the game and specific stakes, irreducible to the rules of the game and the stakes of other fields

Submit Date: 03.04.2019, Acceptance Date: 04.08.2019, DOI NO: 10.7456/10904100/006 
(Bourdieu, 1993). Enwistle and Rocamora's (2006) interpretation of fashion shows within the field theory is an important approach when evaluated together with the participants, audience, journalists, designers and venues upon which they are presented. Thus, the artistic and technological presentation of stories, together with their philosophical interpretation and the myths that fashion shows elaborate creates a bond among actors within the field through connective narratives. Designers also reinforce their interaction with the audience in order to strengthen their work and to communicate the correct effect or message though performance arts.

The catwalk arena is a particularly visible realm where identities are created through very visible performances (Enwistle and Rocamora, 2006: 744). In most cases, fashion shows can be read as minidramas; complete with characters, themes, music and a specific location. They have also been referred to as "theatre without a plot" (Duggan, 2001: 246). For this reason, it could be said that there is a narrative side to each fashion show. Since the mid-1990's, designers like the late Alexander McQueen and John Galliano (designing for Givenchy and Christian Dior respectively) earned reputations for fashion shows that read like sequences of dream images or fantastical visions. Staging their events in sites such as train stations, hospital wards and aircraft hangars, contemporary designers create elaborately orchestrated events that rival theatrical productions (Duggan, 2001: 244). An example of such an event would be Chanel's transformation of the runway into a supermarket for its 2014 fallwinter collection fashion show, in which the fashion house demonstrated the supermarket concept with models running with supermarket carts, packed with Chanel bags (Picture1). At the end of the show, candy and fresh fruits were shared with the audience together with an announcement that enabled the participation of the audience in the process and the story created (King, 2014). There are certain factors that make it possible for 20-25 minute fashion shows to stick in the minds of the audience. Fashion shows are not only a means to present new designs; there are several factors that create a minutes-long visual parade in the memory of the audience, and reflects the "concept" to the viewers and relates this concept to the designs. Since they have an atmosphere surrounded by music, video arts, performances and stage design, fashion shows can leave a powerful impression. Hussein Chalayan is famous for presentations beyond that of the conventional catwalk. His intellectual staging of creations explore well-beyond the orthodox boundaries between fashion, design, performance and art. His collections and shows are concerned with issues like expulsion, identity, isolation and the fate of refugees. To some extent, these topics have autobiographical traits for the Turkish-Cypriot designer (Loschek, 2009: 83). These shows, where a designer's collection is offered, reflects the designer's ideas and inner world through the use of colors, textures, stories, forms and visuals.

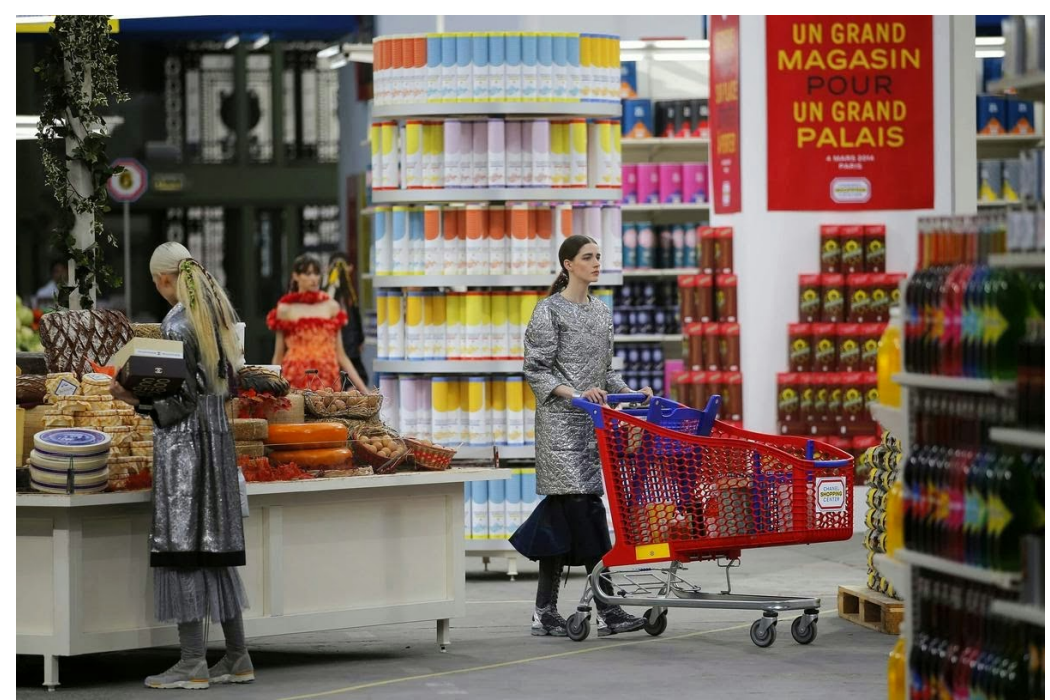

Picture 1. Chanel 2014 fall-winter collection show (URL-1, 2014). 
In the 2014 winter collection show, designers Humberto Leon and Carol Lim used New York's fashion week to celebrate the opening of brand stores of Opening Ceremony in Belgium. In their show, melted "Callebaut" chocolates spilled from a platform on the stage in order to create texture on the walls of the scene (Picture 2). The scent of chocolate filled the room during the show and at the end, the audience were invited to break off the chocolate from the walls and taste it; thus, the stage design went beyond satisfying only the visual sense, but stimulated both olfaction and palate of the audience in a participatory experience that resembled Belgium. Within this example, fashion shows should be considered not only in terms of the visual sense, but also as a show that appeals to all five senses through specifically prepared presentations. This situation is also causing audiences to share different types of sensual experiences which creates changes audience's expectations. Thus, designers seek versatile contributions for their presentations.

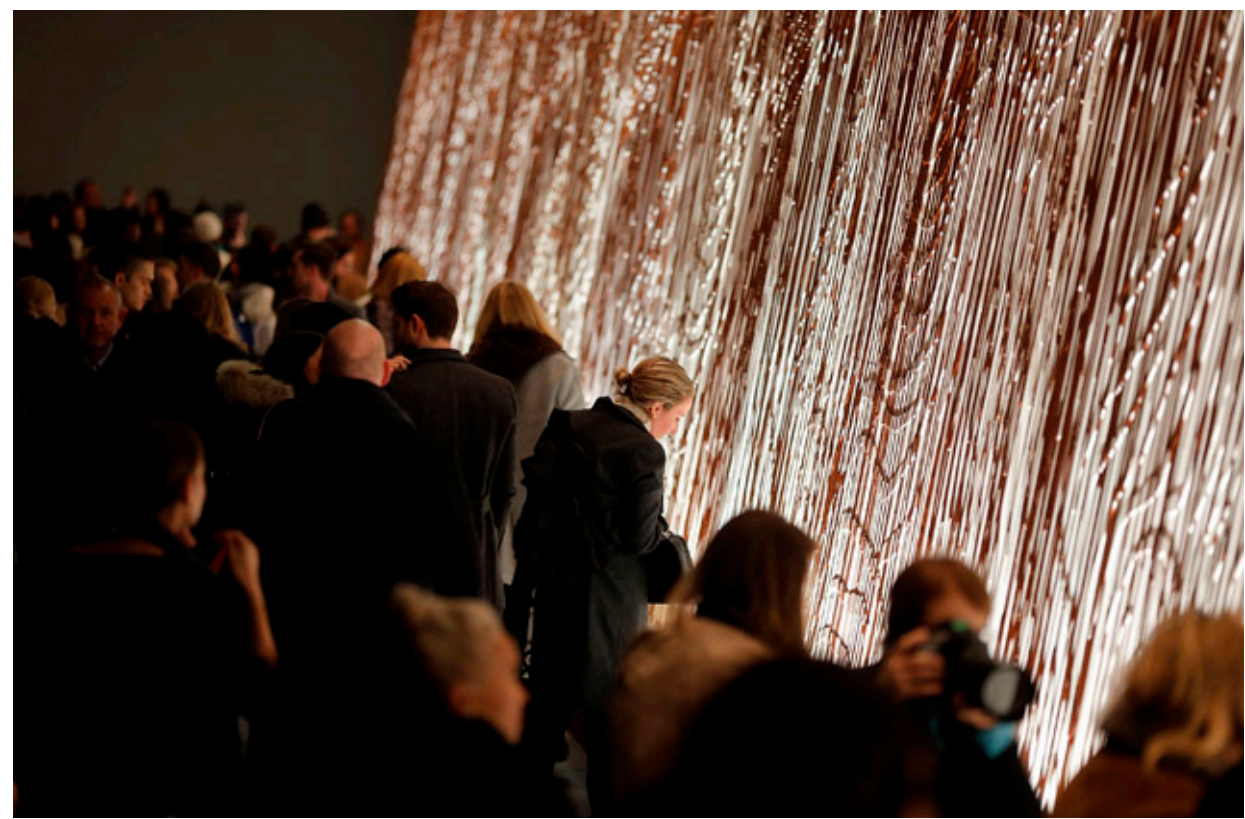

Picture 2. Chocolate coated walls at Opening Ceremony show (URL-2, 2014).

With the widespread art of the fashion show and the developments of public catwalks, fashion shows have become more and more part of public recreation (Xu and Zhang, 2011: 609). Thus, to reflect the sentiment of a collection as accurately as possible, organizing a fashion show requires a significant degree of artistic approach. At this point it can be argued that throughout history, the interaction between fashion and art was not limited to creative processes, but also in its presentation and the relay of created products and designs. Of equal importance is that through fashion shows, designers or brands can fully control the aesthetic vision or concept. It is now the fashion show that makes a designer an artist, and not merely a dressmaker (Skov et al., 2009: 3). It can be argued that through performance, fashion designers have adopted a role of "designer-as-artist" (Duggan, 2001: 268). Artistic perspective is not limited to the creation of fashion trends and designs, but is now a requirement of fashion shows as well. Thus, the fashion and art world is now close to being an "art of fashion shows."

One of the most significant stage designers has been Alexandre de Betak. This chief designer in the French design house of Bureau Betak has become one of the most powerful names in the field through his stage designs over more than 25 years. The designer has worked with John Galliano, Hussein Chalayan, Christian Dior, Victoria's Secret, and Viktor and Rolf. The designers pulled the collection pieces from the models and hung them on the stage walls in Viktor and Rolf's fall-winter 2015 show, and realized a performance that reflected the central theme of the collection inspired from picture frames. Designers also collaborate with the art of cinema. An example took place with Kenzo and Submit Date: 03.04.2019, Acceptance Date: 04.08.2019, DOI NO: 10.7456/10904100/006 550 
David Lynch. When Kenzo was inspired from David Lynch movies for 2014 fall-winter creations, Lynch designed the stage and musical arrangements for the show. The daunting stage that included hyper-reality elements made a reference to the red room in the Twin Peaks television series.

Recently, some fashion shows have used digital images and omitted traditional elements of the fashion show such as models, stages, garments, music and even audiences (Hong and Kim, 2014: 1). Kenzo's Spring-Summer 2013 show at Paris Fashion Week was a $22 \times 8$ meter-high cube onto which projections from eight synchronized 22,000-lumen projectors created busy and colorful scenography in order to create a digital jungle environment. In another example, Bureau Betak, in the Peter Pilotto for Target launch at Gotham Hall, placed modular screens and mirrors on the stage and reflected both the designs of Peter Pilotto's collection and Target's logo on the screen using mapping and video graphics. Es Devlin is also known as a stage designer which designed Louis Vuitton's Spring-Summer 2015 show by using gigantic mirrors and LED screens for an audience communication tool from the inside of the stage itself.

For Marc Jacobs' fall-winter 2014 collection, 500 grey and violet foam clouds were mounted on the catwalk ceiling. The "Happy Days Are Here Again" song, sung by actor Jessica Lange, reflected a dark and powerful period instead of happy and good times. The stage designer for the show, Stefan Beckman, said "We wanted the clouds to be grey, not happy and white," and the designer Marc Jacobs said "It is necessary to transmit a little discomfort in the emotion of comfort," and these comments reflected their views on the types of emotions communicated to the audience according to the intended atmosphere created by the show (Colman, 2014).

Values, images, concepts and social environment are all elements that affect people and are deeply rooted in their own biographies (Volonté, 2012: 408). DKNY's Spring-Summer 2015 collection which was named "New York Nation" is an example of Volonté's comment. In this collection, Karan stated that the baseline of the collection she took inspiration from was the lights, energy and art of New York City (Adams, 2014). DKNY has succeeded in constructing a universe of sense through objects and images tightly interwoven with visions of New York; it is not only a fashion brand, but a collection of symbols and stories of American culture as well as upper-class New York City women (Odabaşi, 2018: 378). According to Elizabeth Currid, New York City is often an inspiration for artists and designers because of its modern, social, dynamic, active and vibrant structure (Currid, 2007: 1-3). New York is a global city that determines and influences various movements worldwide (Warf, 2000). The neon colors used for the collection reminded the audience of city lights. Kepes explained the effects and inspiration of city lights on the audience as rich aesthetic potentials for creating color palettes of the new urban art that would help to connect to the urban character (1996: 187). Based on this assessment by Kepes, it could be argued that city lights are a very effective element in the creative process for artists and designers; it is possible to perceive city lights as one of the opportunities of inspiration offered to an audience. For this show, DKNY also used the different colors and textures of the city as a display for the catwalk; with constructions of Brooklyn Bridge, wall bricks, and pinkish colors of the streets. The various components of the shows -model choice, music, visuals, stage design and location- are further enhanced by the introduction of a theme. Often culled from a source of inspiration for the season, themes can be specific or very abstract. Because these themes are used for many purposes, including the show's invitation, the production, and the clothing line itself, they must be easily identifiable and memorable (Duggan, 2001: 248).

The Italian fashion brand Gucci, exhibiting the fall-winter 2018/2019 collection, had one of the most bizarre promotions in history. The podium was a hospital corridor with operating room lights (Picture 3). The models carried a copy of their head in their hands or a baby dragon as a purse which all bore similarity to the art-works of sculptor Patricia Piccini. Some of the models had a third eye or horns. The designer, Alessandro Michele's interpretation for the show was that humans are the Dr. Frankenstein of their own lives (Mower, 2018).

Submit Date: 03.04.2019, Acceptance Date: 04.08.2019, DOI NO: 10.7456/10904100/006 


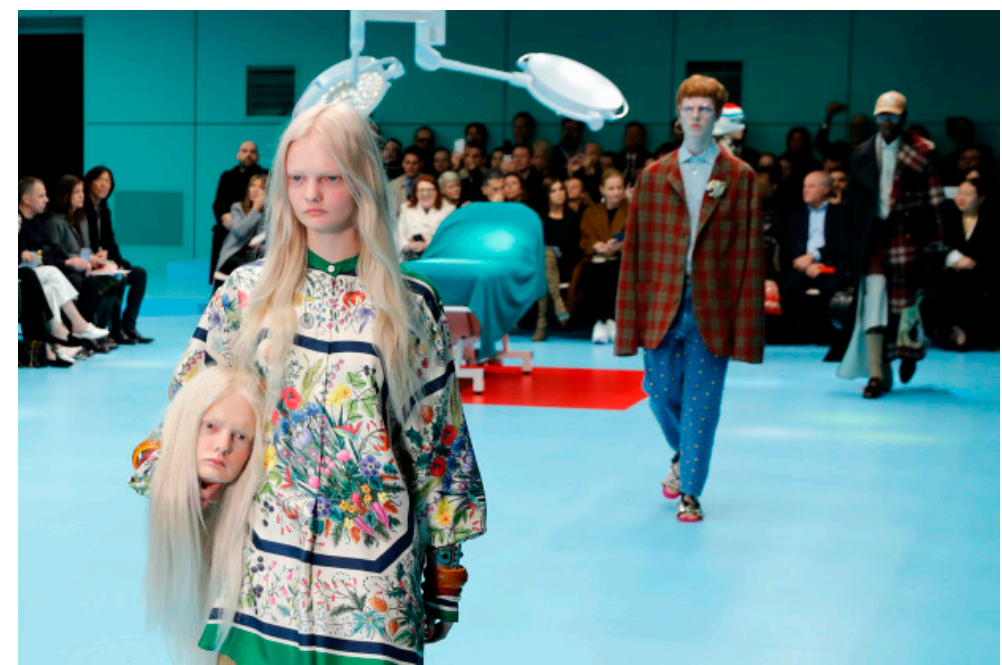

Picture 3. Gucci fall-winter 2018/2019 collection (The Mercury News, 2018).

\section{CONCLUSION}

According to Barthes, fashion is not only what women and men wear; fashion designers' inventions please or annoy us just like a film or a novel (2013: 103). Thus, it can be said that designers' views and understandings are also important for our own perceptions and interests of fashion. In some cases, the designer's emotions and thoughts are much more resonant than the collection itself, leaving massive effects on the masses. By expressing concepts in creative performances and presenting them in theatricals that narrate small stories, the fashion world is connecting people using verbal culture, stories and myths.

Fashion and its relation to material items such as clothing as well as ideas and practices seems to be about change and the need to display the inventive (Finkelstein, 1996: 4). At this point they are shows where the designer can best convey his/her philosophical views in presentation. While the audial and visual aspects of fashion shows represent the designs, it could be argued that there is also a narrative aspect to every fashion show. Artistic practices and creative productions in fashion shows require considerable artistic investment in the creation of fashion shows. Without doubt, the relationship of the fashion world with the arts demonstrates itself in the fashion shows where it meets with the audience, buyers, retailers and the press.

Today, fashion shows require significant artistic and technological equipment. It is insufficient that just a fashion shows is being held; they have now entered into the expectations of how to present the story being told to the audience. As fashion sense is changing, we must think that fashion shows are also. Considering the relationship between fashion and art, "what is the fashion sense of the 21 st century?" and "what is the art of 21st century?" should also be asked. Given the answer to these two questions in the context of fashion shows, the subject of "technology" is undoubtedly under consideration. With the inclusion of technology in the fields of art and fashion, fashion shows now have a great potential to present almost all kinds of possibilities to the audience with its stimulating qualities and technical aspects. With the advancements in digital arts and technology and the nourishment of fashion through all aspects of art, designers are discovering new ways of reflecting the stories of their collections in more effective and surprising ways.

The common qualities of the fashion shows given in the examples are that the features of real-life spaces are designed to present speculative spaces which creates a feeling of closeness to reality, but also gives a little room of imagination for the future. The meaning of fashion show that is created for only presenting the clothes, is now changing by transferring the spaces of daily life where people

Submit Date: 03.04.2019, Acceptance Date: 04.08.2019, DOI NO: 10.7456/10904100/006 
associate to the stage. Thus, such alienation eliminated where one can find her/himself integrated within this aspect. The proximity here can be also found between the audience and the show. The function of fashion shows is changing from a means of promotional to a method of designer to audience communication. In this paper, it is argued that audiences are also included as participants in these artistic demonstrations; that they are not only watching a fashion show, but also participating in many cases. Fictional places and sets within the show venue are gaining more importance, and the audience in those places are also included as fictional actors. From the examples given above, it can be understood that fashion shows have a different approach today; by inviting the audience to a more participatory arena, audience's role is changing from seeing things to becoming things to be seen in narrations which can be defined as an important shift concerning the conventional fashion shows.

\section{REFERENCES}

Adams, Brittany. (2014). "Spring 2015 Ready-To-Wear DKNY”, https://www.vogue.com/fashionshows/spring-2015-ready-to-wear/dkny (Accessed on: 23.02.2016).

Arnold, Rebecca. (2009). Fashion: A Very Short Introduction, New York: Oxford University Press.

Barnard, Malcolm. (2013). Fashion as Communication, New York: Routledge.

Barthes, Roland. (2013). Fashion Language, Sydney: Bloomsbury.

Bourdieu, Pierre. (1993). The Field of Cultural Production: Essays on Art and Literature, Cambridge: Polity.

Colman, David. (2014). The Cloud-Filled Set of Marc Jacobs's Fall 2014 Fashion Show, https://www.architecturaldigest.com/story/marc-jacobs-fall-2014-fashion-show-clouds (Accessed on: 02.11.2018).

Currid, Elizabeth. (2007). The Warhol Economy: How Fashion, Art \& Music Drive New York City, New Jersey: Princeton University Press.

Davis, Fred. (1997). Moda, Kültür ve Kimlik, (Translation: Özden Arıkan), İstanbul: Yapı Kredi Yayınları.

Duggan, Ginger Gregg. (2001). "The Greatest Show On Earth: A Look At Contemporary Fashion Shows and Their Relationship to Performance Art”, Fashion Theory, 5(3), pp. 243-270.

Entwistle, Joanne. and Rocamora, Agnès. (2006). "The Field of Fashion Materialized: A Study of London Fashion Week", Sociology, 40(4), pp. 735-751.

Finkelstein, Joanne. (1996). Fashion: An Introduction. New York: NYU Press.

Hong, Hye. Rim. and Kim, Young. In. (2014). “Communication Characteristics of Fashion Show Using Digital Images”, Journal of the Korean Society of Costume, 64(6), pp. 1-15.

Kepes, Gyorgy. (1996). “Kent Ölçeğinde Dışavurum ve İletişim Üzerine Notlar”, Cogito, 8, 177-190.

King, Joyann. (2014). "Karl Lagerfeld Stages Chicest Supermarket Ever at Chanel", http://www.harpersbazaar.com/fashion/fashion-week/a1774/chanel-grocery-store-show/ (Accessed on: 11.06.2016). 
Kuruc, Katarina. (2008). "Fashion as Communication: A Semiotic Analysis of Fashion on 'Sex and the City", Semiotica, 171, pp. 193-214.

Loschek, Ingrid. (2009). When Clothes Become Fashion: Design and Innovation Systems, Berlin: Berg.

Marshall, G. and Scott, J. (1998). “A Dictionary of Sociology”, United States: OUP Oxford.

Mower, Sarah. (2018). "Fall 2018 Ready-To-Wear Gucci", https://www.vogue.com/fashionshows/fall-2018-ready-to-wear/gucci (Accessed on: 16.04.2018).

Odabaşi, Sanem. (2018). "DKNY-City Connection: The Impact Of New York City on the Brand and the Designer", International Journal of Fashion Studies, 5(2), pp. 373-380.

Skov, Lise, Skjold, Else, Moeran, Brian, Larsen, Frederik. and Csaba, Fabian. F. (2009). "The Fashion Show as an Art Form", Creative Encounters Working Paper, 32, Copenhagen: Copenhagen Business School.

Svendsen, Lars. (2006). Fashion: A Philosophy, London: Reaktion Books.

The Mercury News, (2018). Photos: Gucci runway show features severed heads, 'dragon's puppies' https://www.mercurynews.com/2018/02/21/photos-gucci-runway-show-features-severed-headsdragons-puppies/ (Accessed on: 06.09.2019).

Tungate, Mark. (2006). Modada Marka Olmak: Armani'den Zara'ya Moda Devlerinin Marka Oluşturma Tarzları, (Translation: Günhan Günay), İstanbul: Rota Publication.

URL-1 (2014). http://tinysparklythings.blogspot.com/2014/03/chanel-goes-grocery-shopping-withready.html (Accessed on: 06.09.2019).

URL-2 (2014). http://www.buro247.me/fashion/news/opening-ceremony-aw14-chocolate-wall.html (Accessed on: 06.09.2019).

Volonté, Paolo. (2012). "Social and Cultural Features of Fashion Design in Milan", Fashion Theory, 16(4), pp. 399-431.

Warf, Barney. (2000). "New York: The Big Apple in the 1990's", Geoforum, 31(4), pp. 487-499. Xu, Yi. and Zhang, Mei. (2011). "An Analysis of Marketing Function of Fashion Shows", R. Wang and L. Huawu (eds.), Advances in Textile Engineering, Switzerland: Trans Tech Publications, pp. 607-610. 